Економічні науки

УДК 332.87

Папіян Едуард Альбертович

студент

Київського національного університету технологій та дизайну

МЕТОДОЛОГІЯ ОБЛІКУ ТА УПРАВЛІННЯ КОМУНАЛЬНОЮ ТА

ДЕРЖАВНОЮ ВЛАСНІСТЮ

МЕТОДОЛОГИЯ УЧЕТА И УПРАВЛЕНИЯ КОММУНАЛЬНОЙ И

ГОСУДАРСТВЕННОЙ СОБСТВЕННОСТЬЮ

\title{
METHODOLOGY AND MANAGEMENT ACCOUNTING MUNICIPAL AND STATE PROPERTY
}

Анотація. У статті визначено та проаналізовано методологію обліку та управління комунальною та державною власністю та систематизовано ї̈ основні принципи. Використано загальнонаукові методи: аналіз $і$ синтез; індукція і дедукція; аналогія і моделювання; абстрагування $і$ конкретизація; системний аналіз. Запропоновано нові критерії для систематизації та удосконалення обліку та управління комунальною та державною власністю в сучасних реаліях.

Ключові слова: комунальна власність, державна власність, облік, управління власністю, єдина інформаційна система ДКВ м. Києва.

Вступ. Управління - свідома цілеспрямована дія 3 боку держави, економічних суб’єктів на людей та економічні об’єкти, яка здійснюється 3 метою направити їх у потрібне русло і отримати очікувані результати [1, с.760].

Одне $з$ найважливіших досягнень теорії прав власності західні економісти вбачають у тім, що вона в явній формі визнала існування альтернативних систем власності та зробила їх предметом порівняльного аналізу. У західній літературі виділяється три основних правових режими власності. 
1. В умовах системи приватної власності власником є індивідуум, чиє слово у вирішенні питань про використання ресурсу суспільство визнає остаточним. Таким чином, окремі індивідууми перебувають у привілейованій позиції щодо доступу до тих або інших ресурсів: доступ відкритий тільки їх власнику або особам, яким він передав або делегував свої права.

2. В умовах системи державної власності вводяться правила, згідно 3 якими доступ до рідкісних ресурсів регулюється посиланнями на колективні інтереси суспільства загалом. Це припускає, по-перше, встановлення правил, що визначають, у чому ж саме полягає колективний інтерес (благо суспільства), а по-друге, розроблення процедур, що переводять цей загальний принцип у конкретні способи прийняття рішень по використанню кожного окремого ресурсу (тобто голосуванням, делегуванням прав професійним експертам, одноособовим розпорядженням правителя тощо). За таких умов жоден не перебуває в привілейованому положенні в тому розумінні, що як індивідууми усі виключені з доступу до ресурсів, оскільки нічиє посилання на особистий інтерес не достатнє для їх використання. Співвласники державної власності не мають одноособових виняткових прав щодо використання ресурсу, які продаються на ринку.

3. В умовах системи комунальної (загальної) власності так само жоден не перебуває в привілейованій позиції, але в цьому випадку, навпаки, доступ до ресурсів відкритий усім без винятку. За обмеженого обсягу ресурсів регулятором стає принцип "перший заволодів - перший скористався".

На думку західних дослідників, ці три системи власності в жодному суспільстві не існують у чистому вигляді, а перемішані у різних пропорціях. При цьому на окремі види ресурсів в усіх суспільствах поширюється одна й та сама форма власності. Так, практично, скрізь предмети одягу перебувають в індивідуальній власності, міські парки - у комунальній, оборона - у державній. Крім того, за системи приватної власності завдяки свободі відокремлення й комбінування часткових право чинностей можуть формуватися форми, що 
імітують державну або комунальну власність (наприклад, акціонерна власність).

Поняття «комунальна власність» з'явилося у законодавстві України в 1990 року з прийняттям Закону «Про місцеві Ради народних депутатів та місцеве самоврядування». Законом України «Про власність» суб'єктами права комунальної власності були визначені адміністративно-територіальні одиниці в особі обласних, районних, міських, селищних, сільських рад.

Виділення системи управління в Україні практично почалася 3 прийняття Конституції України в 1996 року. Подальший розвиток місцевого самоврядування знайшла у прийнятому у 1997 році Закону України «Про місцеве самоврядування». Наступним кроком було законодавчо закріплене приєднання України до Європейської Хартії місцевого самоврядування 1985 року, яка була ратифікована у 1997 році. Здійснення основних положень цієї Хартії, зокрема надання органам місцевого рівня права діяти в межах закону під власну відповідальність - в інтересах територіальної громади.

Конституцією України суб'єктами права комунальної власності, відокремленої від держави, вже стали територіальні громади села, селища, міста, які безпосередньо або через органи місцевого самоврядування управляють майном, що знаходиться у комунальній власності. Відбулося закріплення територіальної громади як суб'єкта місцевого самоврядування. Положеннями ст. 142 Конституції України визначено фінансові засади місцевого самоврядування в Україні, від яких залежить успішність виконання цими органами покладених на них функцій. Тепер все рухоме i нерухоме майно, доходи місцевих бюджетів, земля, природні ресурси, які є власністю територіальних громад сіл, селищ, міст, районів у містах, а також об'єкти спільної власності, що перебувають в управлінні районних, міських, обласних рад є матеріальною і фінансовою основою місцевого самоврядування. 
В сучасній Україні комунальна власність історично відокремилася 3 місцевої державної власності - до 1997 року державна власність поділялась на загальнодержавну та комунальну власність.

Управління державною власністю в України здійснюється на принципах:

- Законності. Необхідно учасникам взаємодії у сфері управління комунального сектора економіки України дотримуватися законодавства для фактичного досягнення загальності права, реалізації прав і свобод.

- Прозорості, підзвітності та відповідальності перед територіальними громадами органів місцевого самоврядування та їх посадових осіб за належне та ефективне управління.

Задля розуміння функціонування та реалізації принципів на практиці варто розглянути структуру управлінської вертикалі наведеної на рис. 1.

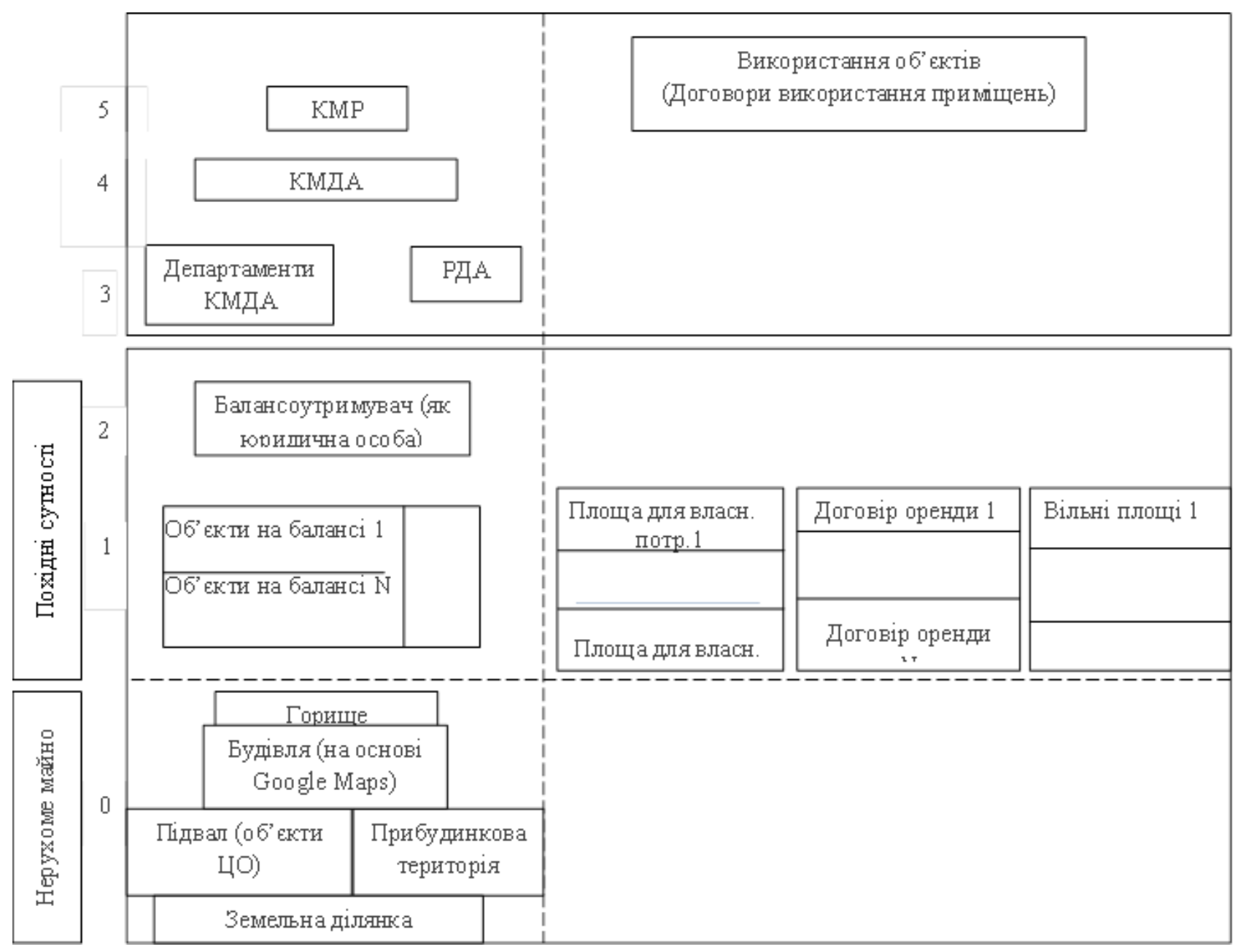

Рис. 1. Структура управлінської вертикалі 


\section{Пропозиціï:}

Об’скт - частина майна нежитлового фонду м. Києва, що належить до комунальної власності, щодо якої нормативним актом Київської міської ради визначено орган управління та балансоутримувача майна, для здійснення управлінських рішень (прийняття об'єкту на баланс, передачі об'єкту з балансу, списання об'єкту з балансу шляхом зносу, списання об'єкту з балансу шляхом приватизації, постановка новозбудованого об'єкту на баланс) 3 метою ефективного його використання (для власних потреб, для передачі в оренду).

Будівлі - основа для прив'язки та ідентифікації об'єктів яка має технічний паспорт, технічні характеристики, відомості про прибудинкову територію.

Нежитлове приміщення - ізольоване приміщення в багатоквартирному будинку, що не належить до житлового фонду і $\epsilon$ самостійним об'єктом нерухомого майна та самостійним об'єктом цивільно-правових відносин.

Суб'єктами процесу використання комунального майна м. Києва є:

- КМДА - стосовно майна що знаходиться у спільній власності територіальних громад міста;

- РДА - стосовно майна територіальних громад міста;

- Комунальні підприємства, установи, організації - балансоутримувачі комунального майна міста.

До однієї з базових проблем використання комунального та державного майна відноситься розподіл його на будівлі та споруди.

Логічним результатом діяльності людей в частині захисту від оточуючого середовища стала поява будівель i споруд. Раніше для їx зведення використовувалися примітивні будівельні матеріали, а сьогодні - передові технології, що прискорюють виробничі процеси і захищають екологію. Терміни « будівля » і «споруда » використовуються як синоніми, проте насправді їх значення має свої особливості. 
Будівля - наземна конструкція, що володіє приміщеннями і призначена для постійного або тимчасового перебування людей. Поверховість не обмежена: вони можуть бути як невеликими (котедж, дача), так і гігантськими ( хмарочоси, висотки ). Будівлі можуть використовуватися як для проживання людей, так і для виробничої, сільськогосподарської діяльності, суспільних потреб, як складу або сховища. Його найважливіший атрибут - капітальність, тобто тривала експлуатація.

Споруди - об’єкти, що виникли в результаті цілеспрямованої будівельної діяльності людини. У технічній літературі даний термін використовується як антипод поняттю « будівля ». До споруд відносять як пам’ятники, так i утилітарні об’єкти: мости, вежі, тунелі, бункери, притулку та багато іншого. Вони зводяться із застосуванням капітальних технологій і розраховані на тривале використання.

Історично будівлями називалися ті будови, які володіють надземною частиною та відокремленими приміщеннями. Частина 3 них пристосована для проживання, частина - для навчання, виробництва, занять спортом. Спорудами називався будь-який об'єкт, зведений людиною, будь то стадіон, бункер, вогнева точка, колона і т. д. При цьому вони можуть бути повністю позбавлені надземної частини. Будівля - поняття більш вузьке, яке використовується для позначення певної категорії будов. Так, для них характерна наявність приміщень, пристосованих або для проживання, або для іншої діяльності. Як споруди, так і будівлі належать до капітальних конструкцій і призначені для тривалого використання.

Найважливіша ознака споруд - технічне призначення: очищення автомобілів (автомийка), доставка води (каналізація, акведук), транспортування людей (метрополітен). Вони також можуть мати культово-релігійний характер, виступати як пам’ятки архітектури.

Відмінність будівель від споруд полягає в наступному: У юридичному сенсі, споруда - поняття більш широке, ніж будівля, повністю включає його в 
свій обсяг. У технічному відношенні будівлями називають все, що не можна віднести до категорії споруд. Будівлями називають будови, пристосовані для роботи, навчання та проживання людей. Спорудами - ті об’єкти, які виконують технічну функцію.

На відміну від споруди, будівля завжди володіє відокремленими приміщеннями та архітектурної завершеністю. Біля будівлі завжди є надземна частина, яка i складає його основу. Спорудження може повністю розташовуватися під землею.

В Україні діє Державний класифікатор будівель та споруд (ДК БС) який є складовою частиною Державної системи класифікації та кодування технікоекономічної та соціальної інформації. Класифікатор розроблено відповідно до Постанови Кабінету Міністрів України від 27.06.1998 р. №971 “Про програму реформування державної статистики на період до 2002 року”.

- ДК БС призначено для використання органами центральної та місцевої виконавчої та законодавчої влади, фінансовими службами, органами статистики та всіма суб’єктами господарювання (юридичними та фізичними особами) в Україні.

- Використання ДК БС забезпечує умови для вирішення таких завдань:

- виконання комплексу облікових функцій щодо будівельної діяльності в рамках робіт 3 державної статистики, включаючи статистику цін на будівельну продукцію;

- проведення робіт з перепису, оцінки та переоцінки вартості і стану будівель та споруд;

- проведення зіставлення національних статистичних даних щодо продукції будівництва 3 даними Статистичної комісії Європейського Союзу (Свростату) та ОOH;

- проведення соціологічних досліджень 3 питань будівництва, забезпечення житлом і різними послугами населення України; 
- розроблення аналітичних показників та прогнозування інвестицій в економіку України.

- Об’єктами класифікації в ДК БС є будівлі виробничого та невиробничого призначення та інженерні споруди різного функціонального призначення.

- Споруди - це будівельні системи, пов'язані 3 землею, які створені 3 будівельних матеріалів, напівфабрикатів, устаткування та обладнання в результаті виконання різних будівельно-монтажних робіт.

- Будівлі - це споруди, що складаються з несучих та огороджувальних або сполучених (несучо-огороджувальних) конструкцій, які утворюють наземні або підземні приміщення, призначені для проживання або перебування людей, розміщення устаткування, тварин, рослин, а також предметів.

- До будівель відносяться: житлові будинки, гуртожитки, готелі, ресторани, торговельні будівлі, промислові будівлі, вокзали, будівлі для публічних виступів, для медичних закладів та закладів освіти тощо.

- Інженерні споруди - це об’ємні, площинні або лінійні наземні, надземні або підземні будівельні системи, що складаються 3 несучих та в окремих випадках огороджувальних конструкцій i призначені для виконання виробничих процесів різних видів, розміщення устаткування, матеріалів та виробів, для тимчасового перебування i пересування людей, транспортних засобів, вантажів, переміщення рідких та газоподібних продуктів тощо.

- Інженерні споруди класифікуються в основному за інженерним задумом, що визначається цільовим призначенням об'єкта.

- До інженерних споруд відносяться: транспортні споруди (залізниці, шосейні дороги, злітно-посадкові смуги, мости, естакади тощо), трубопроводи та комунікації, дамби, комплексні промислові споруди, спортивні та розважальні споруди тощо. 
Узгодженість інтересів територіальних громад та державних інтересів, тобто застосовувати принцип двоєдиної політики у розвитку комунального господарства. В комунальну власність повинні включатися тільки ті об'єкти, фінансування та забезпечення функціонування яких під силу органам місцевого самоврядування.

Склад муніципальної власності повинен грунтуватися на життєво необхідних потребах населення. Тому в неї повинні входити установи, які забезпечують населення водою, електроенергією, теплом у холодний сезон, а також каналізаційною мережею тощо.

Спрямованості на задоволення потреб членів територіальних громад у товарах, роботах, послугах, у тому числі адміністративних.

В майбутньому комунальні послуги для населення повинні бути розширюватися, тому їх ефективність буде запорукою забезпечення невідкладних потреб населення.

Система управління комунальним сектором економіки України передбачає:

- визначення кола підприємств, які повністю підпорядковуються місцевим органам влади і виконують їм властиві функції. Стратегічно важливим на сучасному етапі ринкової трансформації національної економіки $\epsilon$ формування комунального сектора як динамічного елементу економіки, що здатен до підвищення капіталізації активів підприємств. Визначення оптимальних меж державного, комунального та приватного секторів економіки дозволить значно підвищити ефективність використання наявних та оцінити доцільність створення нових активів в процесі функціонування та розвитку суб'єктів господарювання;

- визначення механізму i засобів впливу територіальних громад на господарську діяльність комунальних підприємств;

- встановлення контролю за діяльністю керівників комунальних підприємств. 
Управління здійснюється для виконання повноважень щодо реалізації прав та обов'язків територіальної громади як власника цих об'єктів, пов'язане 3 ïx ефективним використанням та розпорядженням згідно із законодавством України та 3 метою задоволення жителів територіальної громади в якісних громадських послугах. (див. рис. 2).

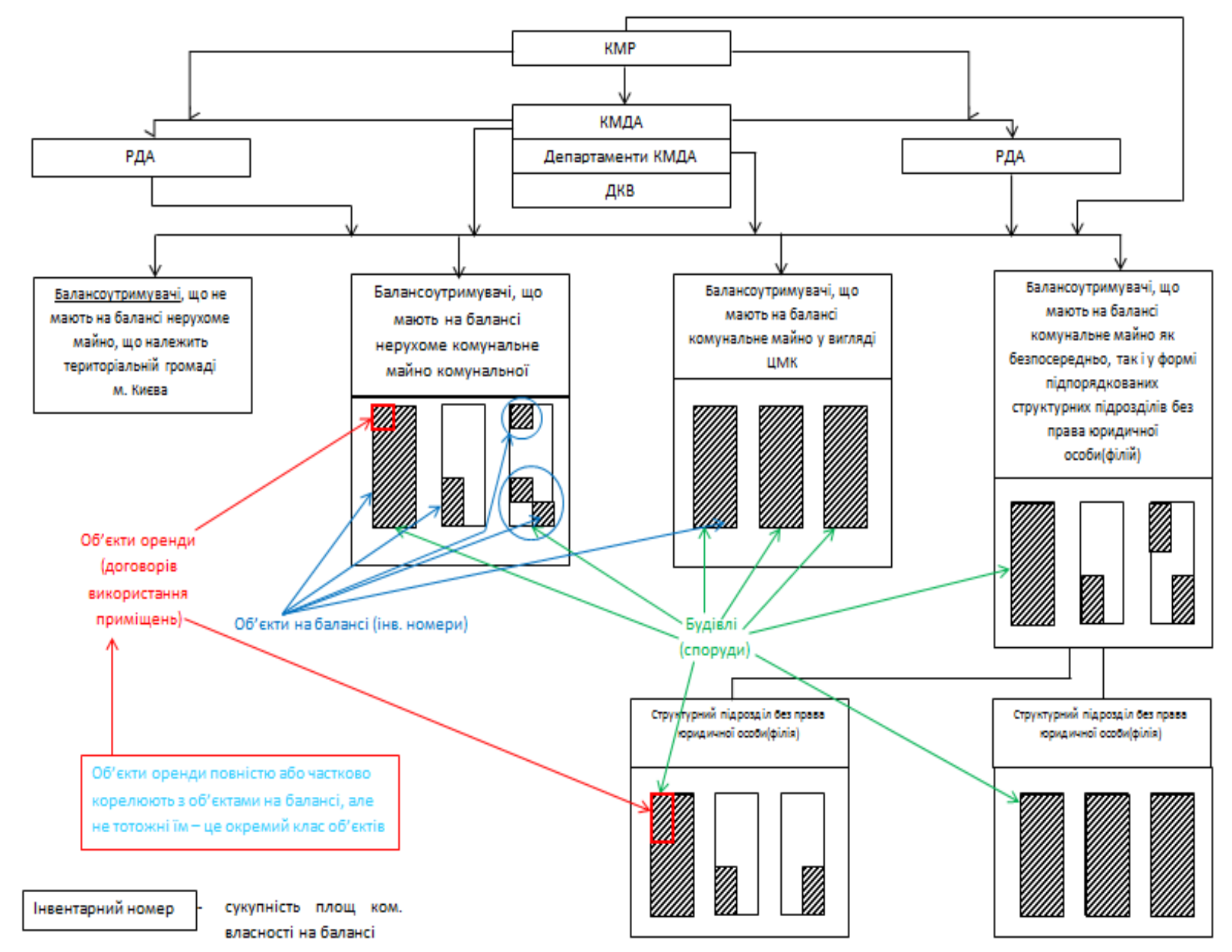

Рис 2. Структура системи управління майном

Управління комунальним майном, яке використовується для підприємницької діяльності, здійснюється для отримання стабільних доходів до місцевих бюджетів.

Для підвищення ефективності використання майна, що є власністю територіальної громади м. Києва впроваджено Єдину інформаційну систему Департаменту комунальної власності м. Києва виконавчого органу Київської 
міської ради (Київської міської державної адміністрації) за участю структурних підрозділів виконавчого органу Київської міської ради (Київської міської державної адміністрації) в тому числі тих, у підпорядкуванні яких знаходяться балансоутримувачі, районних в м. Києві державних адміністрацій, інших органів (підприємств), уповноважених управляти об'єктами комунальної власності територіальної громади міста Києва, балансоутримувачів шляхом об'єднання на єдиних методологічних засадах інформаційних систем з метою:

- ведення обліку об'єктів права комунальної власності територіальної громади міста Києва (далі - об'єкти комунальної власності);

- оптимізації використання об'єктів комунальної власності;

- проведення моніторингу у структурі об’єктів комунальної власності;

- ефективного використання об'єктів комунальної власності;

- забезпечення реалізації управлінських рішень, відкритості та прозорості у використанні об’єктів комунальної власності.

Основними завданнями аналітичної складової є:

- виявлення взаємозалежностей, причинно-наслідкових зв'язків, подібностей і аналогій, визначення часового фактору;

- прогнозування ходу процесів, подій.

- оцінку стану і результатів використання майна;

- постійний контроль за раціональністю ведення господарської діяльності, виявлення резервів для забезпечення виконання поставлених завдань;

- прогнозування ходу внутрішніх процесів на підприємстві і зовнішніх факторів, що мають вплив на управлінські рішення щодо використання майна;

- оцінку ризиків та управління ними.

\section{Висновки:}

1. Об'єкти права комунальної та державної власності повинні використовуватись виключно 3 метою задоволення майнових, а також 
інших законних інтересів членів територіальних громад та громадян в цілому. Використання об'єктів права комунальної власності 3 метою отримання прибутку дозволяється лише за умови підпорядкування цілей отримання прибутку задоволенню інтересів членів територіальних громад. Майнові операції, які здійснюються органами місцевого самоврядування з об'єктами права комунальної власності, не повинні ослаблювати економічних основ місцевого самоврядування, зменшувати обсяг та погіршувати умови надання послуг членам територіальних громад.

2. Розміри муніципальної власності, мають властивості змінюватися, то в бік збільшення, то применшення. Залежить це від економічних змін, а також нововведень у нормативно-правовому регулюванні що вимагає розробки методичних підходів до визначення оптимальної межі комунального сектора економіки України.

3. Забезпечення правової, організаційної та матеріально-фінансової самостійності територіальних громад. Що вимагає використання у їх діяльності диференційованого підходу до вибору форм і методів управління та комплексно-цільовий підхід до організації системи управління, а також оптимізації структури органів управління.

4. Захищеності. Держава забезпечує захист прав усіх суб'єктів права власності і господарювання, соціальну спрямованість економіки. Усі суб'єкти права власності рівні перед законом для чого необхідно провести державну реєстрацію речових прав на нерухоме майно права комунальної власності. 


\section{Література}

1. Борисов А.Б. Большой экономический словарь. Издание 2-е переработанное и дополненное. - М.: Книжный мир, 2006. - 860 с.

2. Эрнандо де Сото. Загадка капитала. Почему капитализм торжествует на Западе и терпит поражение во всем остальном мире / Пер. с англ. - М.: ЗАО "Олимп-Бизнес", 2001. - 272 с.

3. Підопригора О.А. Речові права в проекті нового ЦК України - Бюлетень законодавства і юридичної практики України. - 1998. - № 2. - 375 с. - С. 101-120.

4. Ніколенко Ю. В., Ніколенко І. Ю. Теоретичні аспекти реформування власності в Україні - Економіко-правові проблеми трансформації відносин власності в Україні: 36. наук. праць. - К.: Манускрипт, 1997. - 196 с.

5. Хозяйственное право: Учебник. / В.К. Мамутов, Г.Л. Знаменский, К.С. Хахулин и др.; Под ред. Мамутова В.К. - К.: Юринком Интер, 2002. - 912 с. - Библиогр. с. 897-899.

6. Мацько М.А. Теоретичні основи та політико-правові аспекти муніципальної реформи в Україні - Державно-правова реформа в Україні. Матеріали науково-практичної конференції. - К.: Інститут законодавства ВРУ, 2001. - 420 c. - C. 394-397.

7. Первомайский О. Перспективы развития коммунальной собственности в Украине. - Підприємництво, господарство і право. - 2001. - № 2. - С. 3033.

8. Гриффитс А., Стюарт У. Экономика для бизнеса и менеджмента - Пер. с англ. - Днепропетровск.: ТОВ "Баланс Бізнес Букс", 2007. - 916 с.

9. Проміжний рівень управління в європейських державах: складність проти демократії? / За ред. Т. Ларссона, К. Нодмена, Ф. Петітвілля. - К.: К.І.С., 2003. $-346 \mathrm{c}$. 